\title{
Impact of Social, Epistemic and Conditional Values on Customer Satisfaction and Loyalty in Automobile Industry: A Structural Equation Modelling
}

\author{
Zubair Hassan \\ PhD Candidate \\ Faculty of Economics and Management Sciences \\ International Islamic University, Malaysia \\ Zubai7@gmail.com
}

Received: 26 December 2016/ Revised: 5 March 2017/ Accepted: 28 March 2017/ Published online: 26 April 2017

\begin{abstract}
The purpose of this study is to identify the social, epistemic and conditional values associated with automobiles and to examine their impact on customer satisfaction and brand loyalty. A sample size of 198 respondents was chosen from various locations near Jeddah in Saudi Arabia using convenient sampling techniques. A multi-factor customer perceived value questionnaire with a Likert scale from 1 to 5 was used to collect the data to determine the social, epistemic and conditional perceived values associated with automobiles and their impact on customer satisfaction and brand loyalty. AMOS was used to generate the result and to analyse the collected data. 5 items were reduced from the original construct to meet the standard loading during the confirmatory factor analysis. Then structural modelling was conducted on a full model and satisfaction as a mediator model. The findings were that epistemic value and conditional value have a positive and significant impact on satisfaction. Also epistemic value and satisfaction have a positive and significant impact on loyalty. However, social value has a negative impact on satisfaction and loyalty in the full model and the mediator model as well. Therefore, epistemic value and conditional value are important dimensions or values associated with automobile brands in Saudi Arabia and they affect customer satisfactions and loyalty.
\end{abstract}

JEL classification: M31, M37, M39

Keywords: customer perceived value, satisfaction, brand loyalty

\section{INTRODUCTION}

Customer perceived value (CPV) is a popular topic in marketing and is used by many researchers around the world (Zauner, Koller and Hatak, 2015). Recently, much research has been done on developed and developing countries. A body of research has been done on USA, UK, Spain, Italy, Portugal, Norway and France, representing developed countries, and on Pakistan, UAE, Korea, South Korea, China, Indonesia, Malaysia, Taiwan and Saudi Arabia, representing developing countries (Desmet, 2014). Similarly, much research on CPV associated with products and services from various industries such as IT, food, retail, tourism, airline, online, banking and 
automobile industries was done previously. CPV related studies carried out among the Middle East countries seem to pay very little attention to Saudi Arabia in particular (Chang and Tseng, 2013) except the study done by Moosa and Hassan (2015). CPV was measured in terms of quality, price, design, privacy and satisfaction by many researchers and these measures were found to be the most commonly cited variables in the past. Research shows that there was a positive impact of CPV on retention, satisfaction and customer repeat purchase (Yang and Jolly, 2009). Most of the research shows that CPV has a positive impact on brand loyalty. Also, CPV has a positive impact on retention, satisfaction and repeat purchase (Yang and Jolly, 2009; Vera and Trujillo, 2013; Wu, Chen, Chen and Cheng, 2014).

There are many elements of CPV which impact positively brand loyalty such as price, which is considered the most powerful factor in customer retention for an organisation. Price is an important factor which influences customer decision-making for a product or service. Customers are willing to purchase a new product or service and take purchasing decisions faster when there is a reduction in price (Wu at al., 2014). If the price of a product is not appropriate, then customers might switch to another organisation because they get value for their money (Wu at al., 2014). Emotional value is also considered one of the factors which have high impact on CPV. When it comes to the decision-making, it is important to satisfy consumers psychologically, because emotions play an important role in terms of consumer purchase decision for a product or service (Xiucheng and Yunlai, 2006). Customers emotionally satisfied with a service or product are likely to repeat their purchase. One of the major variables to measure customer perceived value is functional value which meets consumers' requirements for product functions and quality (Peng and Liang, 2013). As some of the authors argued, switching cost is an important variable which has a significant impact on customer loyalty through CPV and satisfaction (Parasuraman and Grewal, 2000). Most research shows that quality has a positive impact on CPV, whereby the customer becomes more loyal toward the organisation. Some research in the past established an association between purchase intension and CPV (Calabuig, Núñez-Pomar, Prado-Gascó and Ano, 2014; Yusof, Singh and Razak, 2013). If the requirements of customers are not fulfilled, there are many negative impacts such as risk of having bad word of mouth from customers, and the image of an organisation will be affected negatively (Loureiro et al., 2012). Oliver and Swan (1989) pointed out that customer loyalty is an important factor which can play an important role in increasing revenue of an organisation.

This paper is organised as follows: the first part is research background and research rationale. The second part is the theoretical framework and research hypothesis development. The third part discusses the research design and methodology, data collection procedures and process. The fourth part presents the results and discussion. The final part is conclusion and recommendations, and implications for further research.

\section{LITERATURE REVIEW}

The most commonly cited definition of CPV proposed by Ziethmal (1988) is overall economic benefits of a product effectiveness. Another definition from the uni-dimensional perspective argued that CPV is overall assessment of the utility of a product in terms of what is obtained and what is paid (Ulaga and Chacour, 2001). One of the most frequently cited multi-dimensional definitions of CPV is proposed by Sheth, Newman and Gross (1991), who argued that CPV is about computation of values that needs to explain why a consumer chooses to buy or not to buy a particular product.

Examining the available literature regarding CPV associated with automobiles around the world, it appears that very little or only a handful of research has been done such as Hur, Kim and Park (2013), Tu, Lin and Hsu (2013), Jalilvand and Samiei (2012), Haq (2012), Leelakulthanit 
and Hongcharu (2012), Yee and San (2011), Yusuf et al. (2013) and Moosa and Hassan (2015). The CPV elements covered in these studies are summarised in Table 1.

Table 1

Elements of CPV associated with automobiles

\begin{tabular}{|c|c|}
\hline Source & Customer perceived value variables \\
\hline Yee and San (2011) & Perceived quality, perceived value, perceived risk, purchasing decision \\
\hline $\begin{array}{l}\text { Leelakulthanit and } \\
\text { Hongcharu (2012) }\end{array}$ & $\begin{array}{l}\text { Economic value, functional values, well-being value, nature lover value, } \\
\text { self-efficiency value, self-expressive value }\end{array}$ \\
\hline $\begin{array}{l}\text { Jalilvand and Samiei } \\
\text { (2012). }\end{array}$ & Word of mouth, brand image \\
\hline $\operatorname{Haq}(2012)$ & Perceived quality, perceived value, customer trust, loyalty, satisfaction \\
\hline Hur, Kim and Park (2013) & Functional value, emotional value, social value, price consciousness \\
\hline Tu, Lin and Hsu (2013) & Corporate brand image, customer commitment \\
\hline Yusuf et al. (2013) & $\begin{array}{l}\text { Responsibility feeling, environmental values, environmental knowledge, } \\
\text { environmental advertisement, environmental friendly product, purchasing intension }\end{array}$ \\
\hline Moosa and Hassan(2015) & $\begin{array}{l}\text { Functional values, social values, emotional values, epistemic values, conditional } \\
\text { values, loyalty and customer satisfaction }\end{array}$ \\
\hline
\end{tabular}

Table 2

CPV studies done on Saudi Arabia

\begin{tabular}{|c|c|c|}
\hline Source & Industry & Customer perceived value variables \\
\hline Eid (2011) & Commerce (Online) & Quality, privacy, satisfaction, perceived security \\
\hline $\begin{array}{l}\text { Abu Bakar, Al Ruwais } \\
\text { and Othman (2013) }\end{array}$ & Retail/shopping mall & $\begin{array}{l}\text { Physical aspects, reliability, professionalism, helpful, } \\
\text { problem solving, and policy }\end{array}$ \\
\hline Abu Bakar (2014) & Retail & Design, privacy \\
\hline Alsheikh and Bojei (2014) & Mobile banking & $\begin{array}{l}\text { Mobile phone experience, awareness of service, } \\
\text { performance expectancy, effort expectancy, } \\
\text { perceived cost, perceived risk }\end{array}$ \\
\hline Moosa and Hassan (2015) & Automobiles & $\begin{array}{l}\text { Functional, social, emotional, epistemic, } \\
\text { and conditional values }\end{array}$ \\
\hline
\end{tabular}

The studies done to examine the CPV associated with automobiles in Saudi Arabia or Middle East are far fewer or it seems that no research has been done except Moosa and Hassan (2015), who carried out the research on examining the impact of CPV using Seth et al.'s (1991) consumption value framework from multidimensional perspective in Saudi Arabia.

The study done by Moosa and Hassan(2015) used customer satisfaction as a mediator between CPV and loyalty, although it used regression values generated to establish the relationship between CPV and brand loyalty using satisfaction as a mediator. The method used to analyse the mediator factor seems not appropriate or accepted by many scholars in the relevant field. Therefore, it is important to review more relevant research before proceeding to conclude with a conceptual framework and analysis. This study discussed the key limitations of Moosa and Hassan (2015) and the reason for using Structural Equation Modelling to establish the original path diagram or conceptual framework used by Moosa and Hassan (2015). The study done by Bakon and Hassan (2013) was considered as the first empirical research conducted using the five consumption values originally established by Seth et al. (1991). For this reason, this study adopted the three key elements of the same theoretical framework: the three CPVs of social (SV), epistemic (EPV) and conditional values (CV), where the first two values were found insignificant 
in influencing both satisfaction and loyalty (Moosa and Hassan, 2015). Therefore, in this study only social and epistemic values are considered as there were various studies done elsewhere that found that these two values have a significant influence on customer satisfaction and loyalty. The third value of conditional value is also considered as in Saudi Arabia, only men are allowed to drive automobiles, which may have some influence on the level of loyalty or satisfaction. Each multi-dimensional value in relation with customer satisfaction and loyalty is reviewed below.

\subsection{Social Value and Customer Satisfaction}

Social value has a direct relation with social status. This dimension has a wide concept which includes social capital and citizens' well-being as well. This can be the ability to take part in decision making that affects them. Perceived social values have a significant positive effect on customer satisfaction with respect to green innovation as a key attribute of the automobile (Hur et al., 2013). Further, customer satisfaction leads to customer loyalty, while lowering price consciousness. Researchers tend to relate social values as social interactions, sociability and hospitality (Payne and Holt, 2001). Personality and own self-image were evaluated during the process of decision making as it is believed that both personality and self-image alignment creates more acceptance in the society (Chon, 1992; Tabassum, Zafar, Ali, Alam and Ali, 2013). Celebrity status associated with a particular product attracts many people's attention (Lee et al., 2008). Buying socially recommended products through media or friends is a usual practice to obtain satisfaction (Miguens et al., 2008). Popular or socially more accepted automobiles create a better image and greater acceptance among people (Mahika, 2011; Tabassum et al., 2013). Social relationships are a motivating factor for many people to create satisfaction and loyalty (Vuuren and Slabbert, 2011). Meanwhile, Sheth et al. (1991) argued that social value is the acceptability of consumers' relationship with the social environment. Social values are considered to be the most important multi-dimensional variables which influence consumers and their purchasing intentions, which has a direct impact on customer satisfaction. In the past, a handful of research was done to explore the impact of these variables on brand loyalty, especially among automobile manufacturers (Eid, 2011; Abu Bakar, 2013; Alsheikh and Bojei, 2014). However, Moosa and Hassan (2015) found that social values do not have any significant impact on customer satisfaction and loyalty. Since the past research brought mixed results, it is important to consider this value and test it to examine whether social values have a positive and significant impact on customer satisfaction and loyalty.

\subsection{Epistemic Value and Customer Satisfaction}

Sheth et al. (1991) defined epistemic value as "capacity of the product or service to satisfy the desire for knowledge". Epistemic value refers to novelty value as well as value gained from learning a new way of doings things such as experience or knowledge gained through testing or exploring new services. Epistemic values can influence the customer intension, which has a direct impact on customer satisfaction and loyalty (Cheng et al., 2009). Similarly, Chang et al. (2013) found that epistemic values have a positive influence on customer satisfaction and loyalty. In their study, epistemic value associated with e-store is translated to utilitarian and hedonic values where perceived value and utilitarian value exert a bigger influence than hedonic value resulting in more brand loyalty. In terms of measuring CPV associated with automobiles, variables such as epistemic values seem quite applicable to measure CPV of a car (Ehsani and Hashim 2015). However, recent studies have found that epistemic value does not have a significant influence on customer satisfaction and loyalty in the automobile industry (Moosa and Hassan, 2015). 


\subsection{Conditional Value and Customer Satisfaction}

Conditional value is perceived benefit gained in a particular situation. It reflects the circumstance in which some market choices are dependent on the particular situation faced by the consumers of a product or service (Sheth et al., 1991). Meanwhile, Ehsani and Hashim (2015) argued that conditional values are appropriate to measure CPV of a customer perceived value associated with automobiles. Conditional values arise when a need is fulfilled using a specific service or product. Sweeney and Soutar (2001) explained conditional value as a specific case of other types of value. Moosa and Hassan (2015) empirically found that conditional values associated with automobiles are significant and positive in influencing customer satisfaction and loyalty.

Therefore, the following hypotheses are formulated:

H1: There is positive and significant influence of SV on customer satisfaction

H2: There is a positive and significant impact of EPV on customer satisfaction

$\mathrm{H} 3$ : There is a positive and significant influence of $\mathrm{CV}$ on customer satisfaction

H4: There is a positive and significant influence of SV on brand loyalty

H5: There is a positive and significant influence of EPV on brand loyalty

H6: There is a positive and significant influence of CV on brand loyalty

H7: There is a positive and significant influence of SAT on brand loyalty

H8: Satisfaction is a partial mediator between EPV and brand loyalty

Figure 1

Conceptual framework

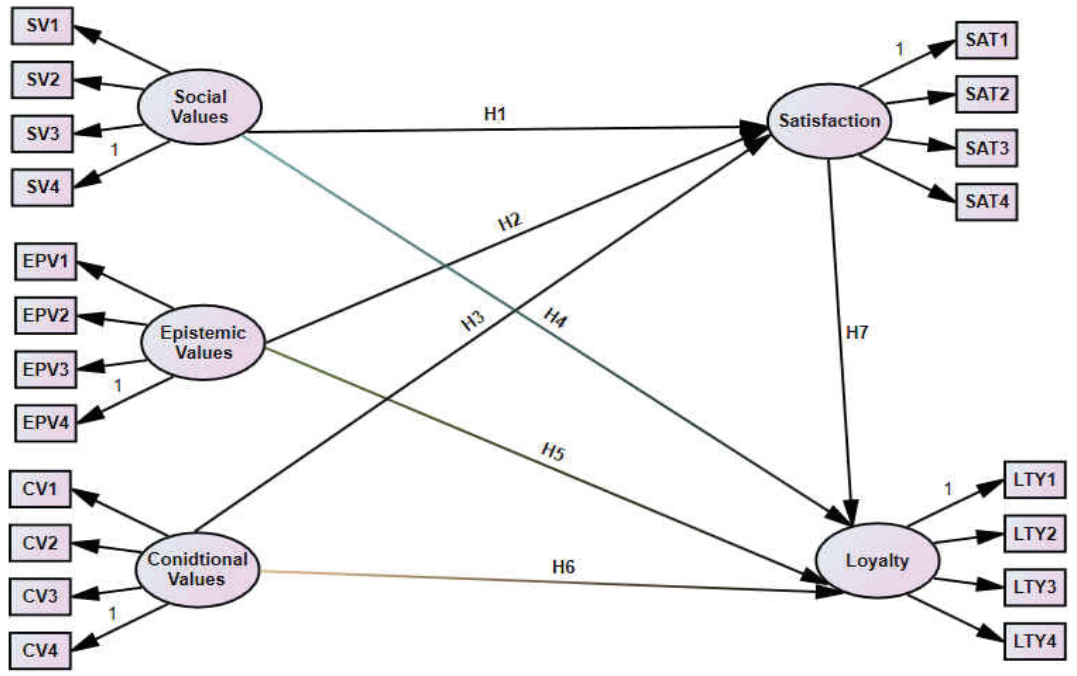

Source: Adapted from Moosa and Hassan (2015)

\section{RESEARCH DESIGN AND METHODOLOGY}

\subsection{Research Paradigm and Design}

The researcher decided to use the positivist paradigm since this research intends to measure causal influences of CPV (independent factor) on customer satisfaction (mediator) and brand loyalty (dependent factor). The casual research design is mainly adopted since this research focuses on testing hypotheses, using a large sample size to generalise the findings (Hair et al., 2009). The research used primary data collected using a rating scale questionnaire (1-5 scale). 


\subsection{Questionnaire}

The questionnaire is designed to gather the data. It consists of three parts. Part 1 deals with personal details such as sex, education, age, etc. Part 2 consists of 12 statements to measure the 3 dimensions of customer perceived value (CPV) such as social value (SV), epistemic value (EPV), and conditional values (CV). Part 3 consists of 8 statements which are divided into two main variables. Four (4) statements were used to measure customer satisfaction and four (4) statements to measure customer brand loyalty. To generate these final 20 items, the following procedures were followed. At first, a total of 12 experts (academicians, marketing and sales managers, and car owners residing in Jeddah) were asked to:

$\checkmark \quad$ Write actual statements that represented the values and items;

$\checkmark \quad$ Clarify the definitions of each value items when it was necessary;

$\checkmark \quad$ Add additional items to the existing value dimensions if it was deemed constructive.

As a result of these procedures, an initial pool of 35 items (representing 7 sub-dimensions) was generated. These items were then incorporated as statements into a measurement instrument utilising a five-point Likert-type scale ( 1 "strongly disagree" to 5 "strongly agree") (Dolnicar, Grun, Leisch and Rossiter, 2011). A panel of four (4) experts in the automobile industry assessed content validity by assessing items on the basis of their relevance and clarity of wording. Items that were endorsed by four (4) experts were retained, whereas items that were deemed to be unclear, irrelevant, or redundant were eliminated. As a result of these procedures, 10 items were eliminated. The remaining 25 items were included in a questionnaire for a pilot field test. The pilot test involved 30 car owners driving the car from their homes to the workplace in Jeddah, Saudi Arabia. The respondents were asked to rate the items to examine the relevance and validity of each item. As a result of this test, none of the items was deleted as these items were found non-ambiguous and reliable.

\subsection{Sampling Method}

A convenience sample of 250 car owners or drivers was recruited to assess internal consistency. Five (5) further items that had been corrected based on factor loading using AMOS, which has a loading less than 0.4, were deleted. After these items had been deleted, Cronbach's alpha coefficients for all factors were greater than 0.70 . Following these scale-purification procedures, the final version of the instrument had a total of 20 items representing 5 sub-dimensions of customer perceived value along with customer satisfaction and brand loyalty (with each subdimension having four items). A total of 211 questionnaires were received (response rate 84\%). However, some of these questionnaires were excluded from the sample as some respondents did not complete the questionnaire. This means that the study only used 198 completed questionnaires (sample size).

\subsection{Ethical Consideration}

Prior to the collection of data, respondents were requested to complete the consent form which was attached to the questionnaire to obtain the permission from each respondent. Participant Information Sheet (PIS) was given to respondents to inform them of the purpose and the importance of this research. The completed questionnaires were collected by the researchers and reminded the respondents to inform the researcher if they wished to withdraw from this study before the data were processed (7 days). 


\subsection{Data Analysis}

Data were analysed using SPSS 21.0 (Field, 2005) and AMOS 22. The goodness of fit of the measurement and structural models was tested using AMOS with the maximum likelihood (ML) method. Goodness of fit of the model to the data was assessed with the comparative fit index (CFI), root mean square error of approximation (RMSEA), and $\mathrm{X}^{2} / \mathrm{df}$ and normed chi-square (Anderson and Gerbing, 1988). The convergent validity of the measures was assessed by factor loadings, AVE values, and reliability coefficients (Hair et al., 2009). Discriminant validity was established when the estimated correlations between the factors or dimensions were found not to be excessively high (Kline, 1998) and when the squared correlations between a construct and any others were found to be less than the AVE for each construct (Fornell and Larcker, 1981).

\section{RESULTS AND DISCUSSION}

\subsection{Descriptive Statistical Analysis}

Descriptive statistics for the 5 dimensions ranged (on a scale of 1-5) from 3.48 (Social Values - SV) to 4.08 (Satisfaction). The standard deviation (SD) ranged from 0.96 to 1.48. Because ML statistics are very sensitive to non-normality (Bentler, 2004), the skewness and kurtosis were examined to ensure that dataset is acceptable in terms of normality. Since many scholars argue if kurtosis and skewness fall between -1 to 1 or if skewness (SK/SE is equal to or less than 2), the dataset can be acceptable for a multivariate analysis. Since the dataset meets the required set of rules, the dataset is considered as normally distributed. All the skewness of the dataset is less than 2.

\subsection{First Order Analysis}

CFA (measurement model) of CPV and Brand Loyalty

To assess the measurement model, two analyses were carried out. First, a first-order CFA was carried out to analyse the measurement model using AMOS 22. The main reason for conducting this analysis is to confirm the latent variables really reflect the intended measures in the instrument. Second, the squared correlation was examined to measure each indicator and to examine whether each item measures a construct (Holmes-Smith, 2001; Hair et al., 2009). The first analysis shows that most of the items in the construct loaded more than 0.5 , which shows a good reliability of the model. The first run of squared multiple correlation showed that the majority of the model is suitable and appropriate (Holmes-Smith, 2001).

To test the reliability of the CPV and its influence on customer satisfaction and brand loyalty instruments, the Cronbach's alpha coefficient was calculated using SPSS 22. Table 1 below shows that Cronbach's alpha exceeds the minimum requirement of 0.70. (Nunnally and Bernstein, 1994). It shows that there is good internal consistency among the variables or elements. The coefficients obtained range from 0.704 to 0.824 (Table 1). The estimates of the standard factor loading were used to determine the validity of CPV dimensions (as shown in Figure 2). The factor loadings in the confirmatory factor analysis ranged from 0.30 to 0.79 for the CPV dimensions. Those which are less than 0.5 are removed from the latent variables since the general rule is to maintain those items that load more than 0.7 (preferred) (Hair et al., 2009) but can include the values that loaded close to 0.5 since the AMOS22 requires minimum four items per construct. 
Figure 2

First measurement model of latent variables

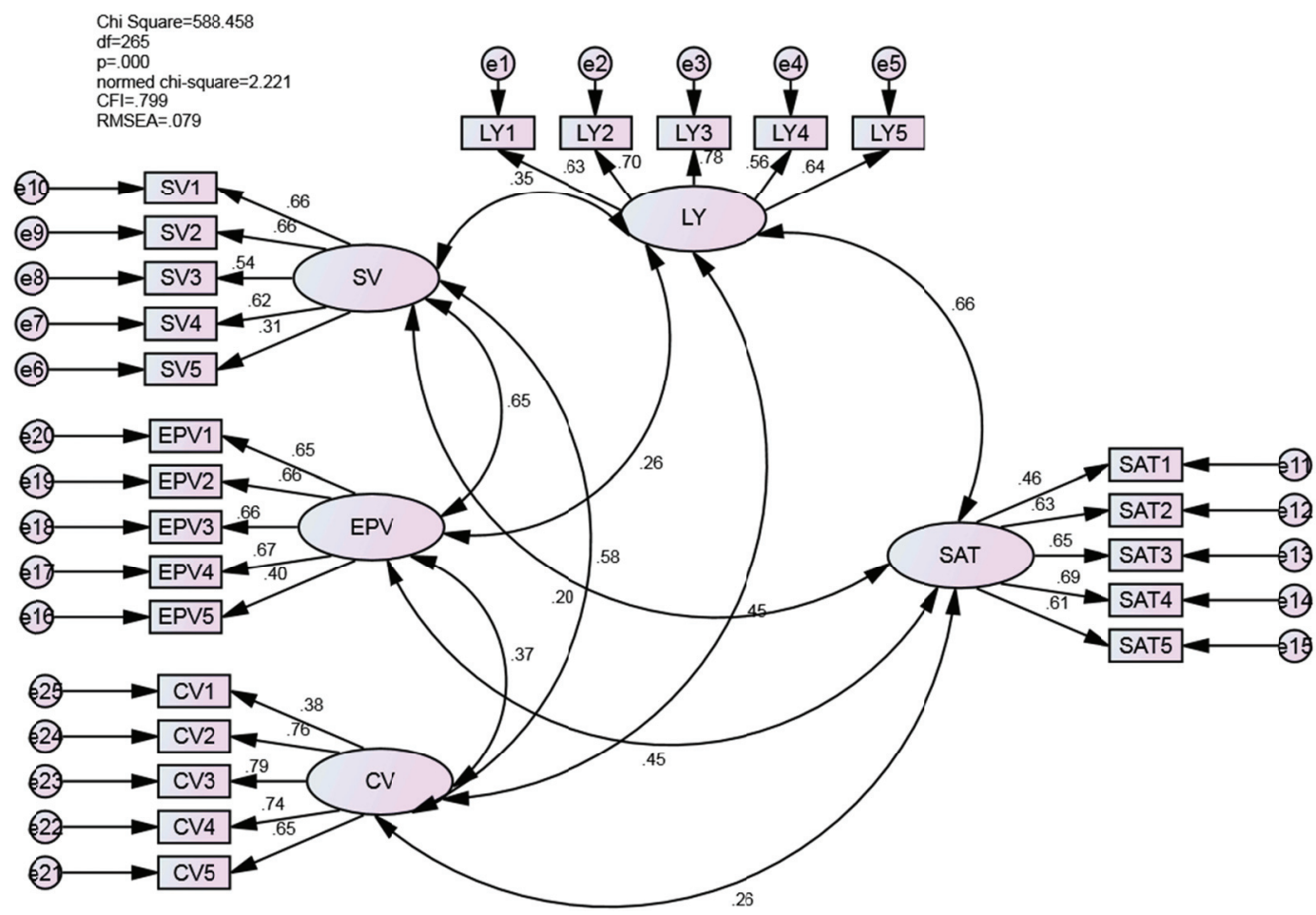

A re-run of CFA carried out, the measurement model result showed that the model was a good fit. Since each construct should have minimum 3 elements (Hair et al., 2009), modification was made using modification indices to ensure that each construct has more than 3 elements as the AMOS 22 requires minimum 4 variables/elements in each construct to successfully run (Figure 2). Table 1 below shows that each element under each construct satisfies the model.

The overall model fit of the measurement model was found to be good. Fit statistics showed that the normed chi-square ratio was below the suggested threshold of 3.0 (Kline, 1998). The RMSEA value of 0.061 was below the recommended threshold of 0.08 (Hu and Bentler, 1999). The CFI of 0.906 was, as recommended, greater than the threshold of 0.9 (Hair et al., 2009). Also the divergent validity of the model was established and justified to ensure model fit shown in Table 3. This means that all the 20 elements used to measure CPV, SAT and LY are acceptable. 
Table 3

Divergent validity of measurement model

\begin{tabular}{|c|c|c|c|c|c|}
\hline & SV & EPV & $\mathrm{CV}$ & SAT & LY \\
\hline SV4 & .645 & & & & \\
\hline SV3 & .467 & & & & \\
\hline SV2 & .714 & & & & \\
\hline SV1 & .611 & & & & \\
\hline EPV4 & & .668 & & & \\
\hline EPV3 & & .673 & & & \\
\hline EPV2 & & .682 & & & \\
\hline EPV1 & & .627 & & & \\
\hline CV5 & & & .644 & & \\
\hline CV4 & & & .743 & & \\
\hline CV3 & & & .809 & & \\
\hline CV2 & & & .751 & & \\
\hline SAT2 & & & & .617 & \\
\hline SAT3 & & & & .644 & \\
\hline SAT4 & & & & .663 & \\
\hline SAT5 & & & & .627 & \\
\hline LY1 & & & & & .704 \\
\hline LY2 & & & & & .757 \\
\hline LY3 & & & & & .587 \\
\hline LY4 & & & & & .633 \\
\hline Construct reliability & .705 & .758 & .824 & .739 & .764 \\
\hline
\end{tabular}

The dataset satisfies the discriminant validity of the sample as all the cross loading is more than 0.5 .

\subsection{Structural Equation Modelling}

A structure model of CPV associated with automobiles and its effects on satisfaction and loyalty in Saudi Arabia was built to estimate the parameters. In this model, there were five models from the first-order and second-order construct. The objective of structural equation modelling (SEM) was to test if CPV affects customer satisfaction and loyalty. The causal structure model of antecedent customer satisfaction and loyalty shown in Figure 3 was designed to test the hypothesis that customer satisfaction and loyalty were influenced by perceived CPV associated with automobiles among the Saudi Arabian drivers. 
Table 4

Discriminant validity

\begin{tabular}{l|c|c|c|c|c} 
& SV & EPV & CV & SAT & LY \\
SV & 1 & .38 & .36 & .01 & .10 \\
\hline EPV & $.62 * * *$ & 1 & .12 & .21 & .10 \\
\hline CV & $.60 * * *$ & $.35 * * *$ & 1 & .06 & .21 \\
\hline SAT & .12 & $.46 * * *$ & $.25 * *$ & 1 & .41 \\
\hline LY & $.32 * *$ & $.23 *$ & $.46 * * *$ & $.64 * * *$ & 1
\end{tabular}

Significance level: $*=0.05, * *=0.01, * * *=0.001$. The values below the diagonal are correlation estimates among constructs. Diagonal elements are construct variance and the values above the diagonal are squared correlations.

There are many ways in which validity of the structural model can be examined One of the ways is indices such as chi-square, normed chi-square, CFI, RMSEA (Hair et al., 2009). Figure 4 shown below indicates that chi-square is significant with $\mathrm{p}=0.000$ (chi-square is $271.434, \mathrm{df}=159$ ). Normed chi-square of less than 3 is considered good fit (Hair et al., 2009). CFI should be more than 0.9. The structural model with modification indices (e7 to e26) indicates that it has a value of more than 0.910, suggesting a good fit. According to Hair et al. (2009), RMSEA should be less than 0.08 . In this case, RMSEA is 0.060 , which is considered as a good fit.

The second way of measuring the validity of the SEM is factor loadings obtained from the measurement model and the full-fledged model that should be very close (Hair et al., 2009). In this case, Table 5 suggests that loadings of the measurement model and structural model are very similar and close to each other. This indicates that the model is validated as a good fit model. The third way of measuring the validity of the structural model is path analysis and its significance. Table 6 shows that in both models the relationships are significant except for SV not significantly associated with SAT (satisfaction). Also SV is negatively associated with satisfaction, indicating that there are some minor issues, but it does not deter the good fit of the construct or model since other path estimates are significant.

Figure 3

Second run and modified measurement model

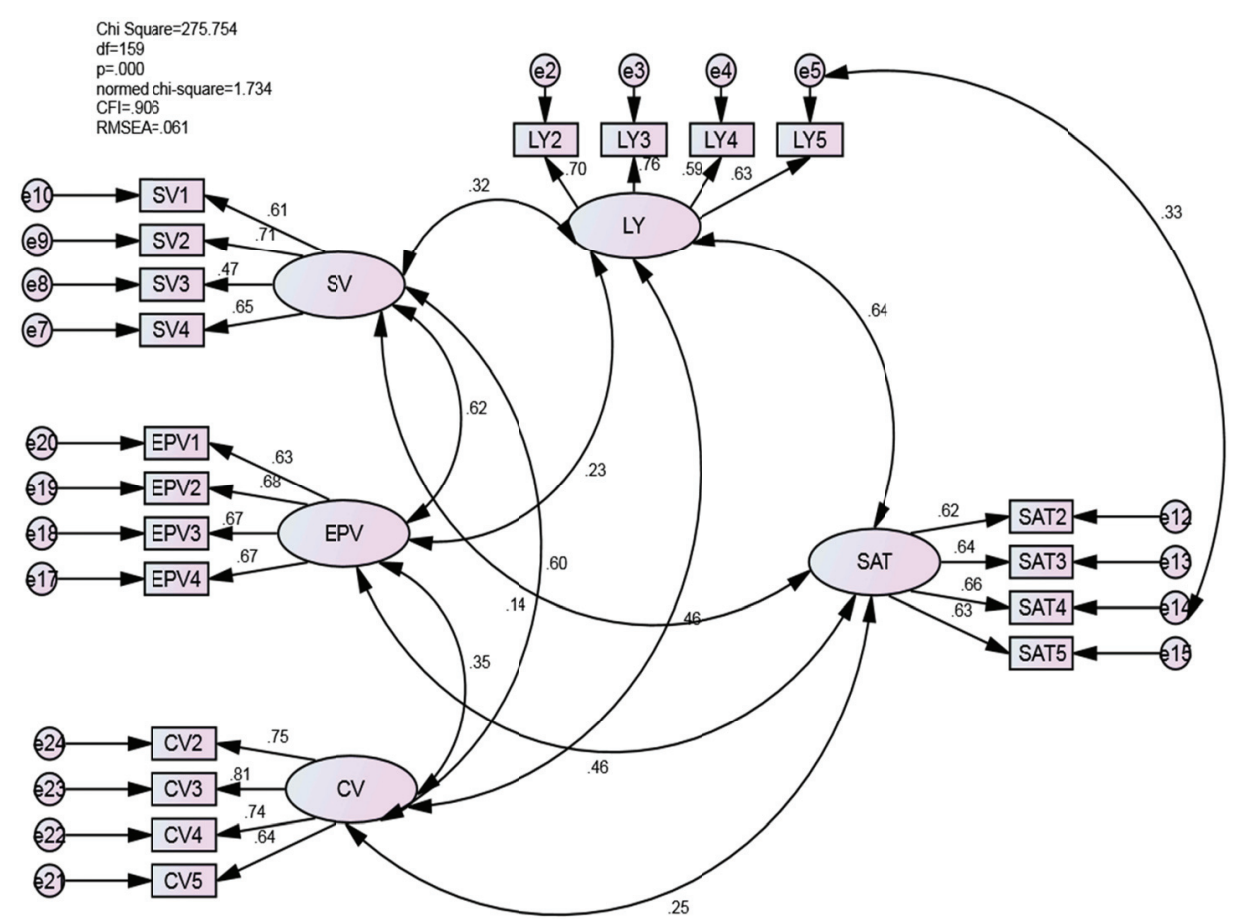


Figure 4

SEM for hypotheses testing

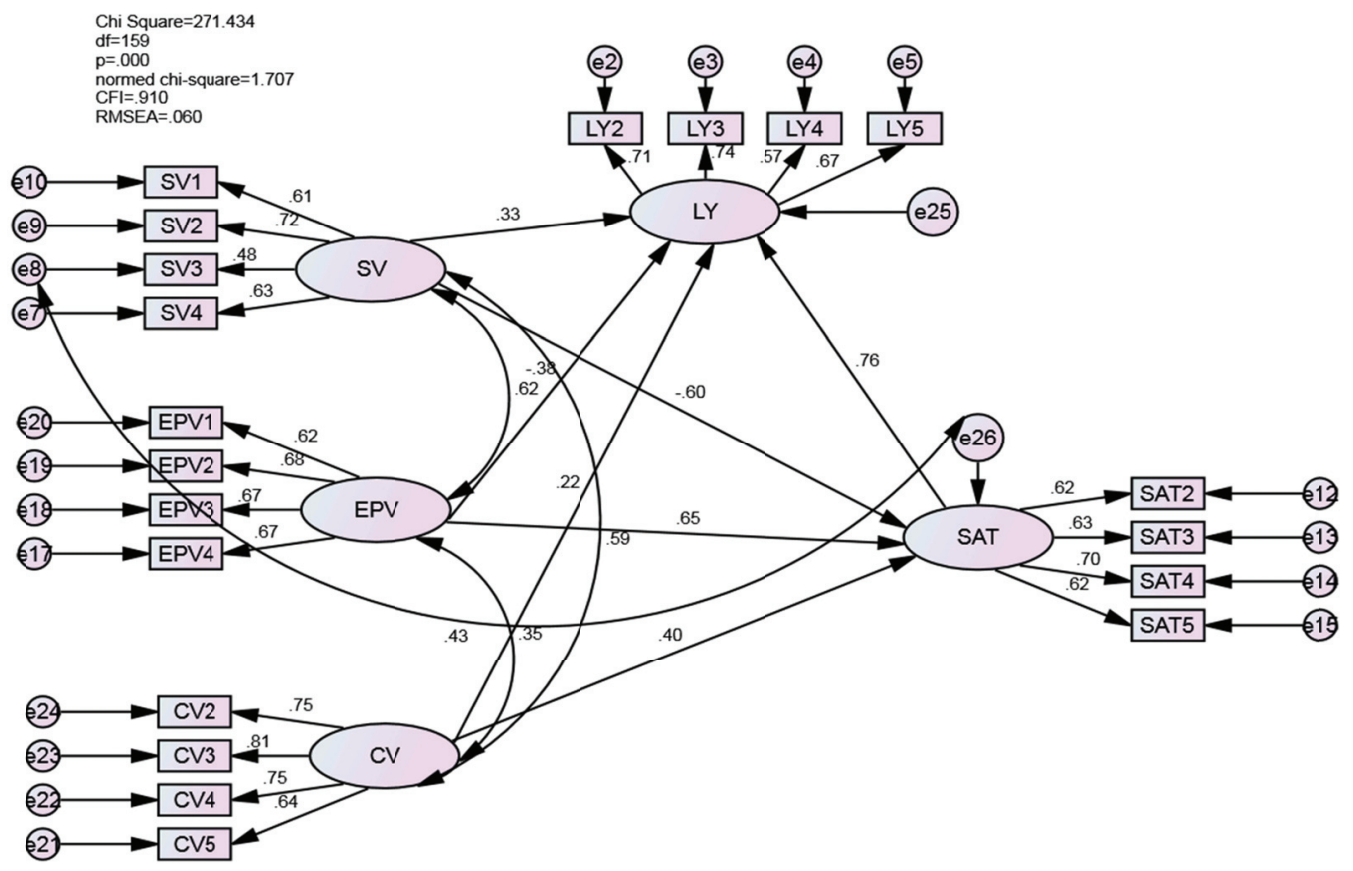

Table 5

Factor loading comparison

\begin{tabular}{|c|c|c|c|}
\hline Indicator & Construct & Measurement model & Structural model \\
\hline SV4 & SV & .645 & .636 \\
\hline SV3 & SV & .467 & .462 \\
\hline SV2 & SV & .714 & .717 \\
\hline SV1 & SV & .611 & .617 \\
\hline EPV4 & EPV & .668 & .665 \\
\hline EPV3 & EPV & .673 & .672 \\
\hline EPV2 & EPV & .682 & .680 \\
\hline EPV1 & EPV & .627 & .619 \\
\hline CV5 & $\mathrm{CV}$ & .644 & .637 \\
\hline CV4 & $\mathrm{CV}$ & .743 & .737 \\
\hline CV3 & $\mathrm{CV}$ & .809 & .823 \\
\hline CV2 & $\mathrm{CV}$ & .751 & .748 \\
\hline SAT2 & SAT & .617 & .626 \\
\hline SAT3 & SAT & .644 & .628 \\
\hline SAT4 & SAT & .663 & .677 \\
\hline SAT5 & SAT & .627 & .630 \\
\hline LY1 & LY & .704 & .697 \\
\hline LY2 & LY & .757 & .731 \\
\hline LY3 & LY & .587 & .559 \\
\hline LY4 & LY & .633 & .654 \\
\hline
\end{tabular}


The overall model indicated that each dimension of the perception of CPV had a positive relationship with customer satisfaction and loyalty. It means that the CPV model is an acceptable and useful instrument to measure CPV dimensions in Saudi Arabia's automobile industry (foreign brands).

The CPV dimension was found to contribute to customer satisfaction and loyalty, and may be a critical aspect for customers in judging the CPV and satisfaction along with loyalty. The standardised parameter estimates and significant values for the hypothesis relationships are presented in Table 6. The findings suggest that the standard structural model of CPV associated with automobiles in Saudi Arabia is a good determinant of satisfaction and loyalty. The standardised regression weight of SV, EPV and CV to customer satisfaction was significant with parameter estimates $(-0.60,0.65$ and 0.40$)$. These regression weights explain the degree of association between the construct and the manifesting variables. In other words, if EPV increased by 1 standard deviation, the standard deviation of customer satisfaction would have increased by 0.65. Furthermore, the significant path coefficient showed that the CV dimension had a positive impact on satisfaction. However, SV had a significant but negative influence on customer satisfaction, which was similar to some past studies done in other parts of the world as well.

Table 6

Path analysis comparison

\begin{tabular}{l|lll}
\multicolumn{1}{c}{ Measurement model } & \multicolumn{1}{c}{ Structural model } \\
\multicolumn{1}{c}{ Relationship } & Parameter estimates & \multicolumn{1}{c}{ Relationship } & Parameter estimates \\
\hline CV correlates with SAT & .25 & H1: CV $\rightarrow$ SAT & .40 \\
\hline EPV correlates with SAT & .46 & H2: EPV $\rightarrow$ SAT & .65 \\
\hline SV does not correlate with SAT & .12 & H3: SV $\rightarrow$ SAT & -.60 \\
\hline CV correlates with LY & .46 & H4: CV $\rightarrow$ LY & .22 \\
\hline EPV correlates with LY & .23 & H5: EPV $\rightarrow$ LY & -.39 \\
\hline SV correlates with LY & .32 & H6: SV $\rightarrow$ LY & .33 \\
\hline SAT correlates with LY & .64 & H7: SAT $\rightarrow$ LY & .76 \\
\hline SV correlates with EPV & .35 & SV correlates with EPV & .34 \\
\hline C correlates with SV & .60 & C correlates with SV & .60 \\
\hline SV correlates with EPV & .62 & SV correlates with EPV & .43
\end{tabular}

Since EPV is the only variable that has a positive and significant impact on customer satisfaction and loyalty, the other two Hypotheses were rejected (CV has a positive impact on loyalty, SV has a significant and positive impact on loyalty) as shown in Table 7. To analyse further whether SAT is a mediator between EPV and loyalty, a mediator analysis was performed. 
Table 7

Hypotheses

\begin{tabular}{|c|c|c|c|c|c|c|c|}
\hline & Hypotheses & & Estimate & S.E. & C.R. & $\mathbf{P}$ & Accepted or rejected \\
\hline SAT & $<---$ & SV & -.599 & .135 & -2.927 & .003 & Rejected \\
\hline SAT & $<---$ & EPV & .651 & .133 & 3.920 & $* * *$ & Accepted \\
\hline SAT & $<---$ & $\mathrm{CV}$ & .403 & .096 & 2.907 & .004 & Accepted \\
\hline LY & $<---$ & SAT & .764 & .167 & 5.002 & $* * *$ & Accepted \\
\hline LY & $<---$ & SV & .329 & .129 & 1.837 & .066 & Rejected \\
\hline LY & $<---$ & EPV & -.385 & .141 & -2.378 & .017 & Accepted \\
\hline LY & $<---$ & $\mathrm{CV}$ & .218 & .094 & 1.764 & .078 & Rejected \\
\hline
\end{tabular}

Figure 6 shows the mediator effect using constrained model.

\section{Figure 6}

Mediator analysis using SAT

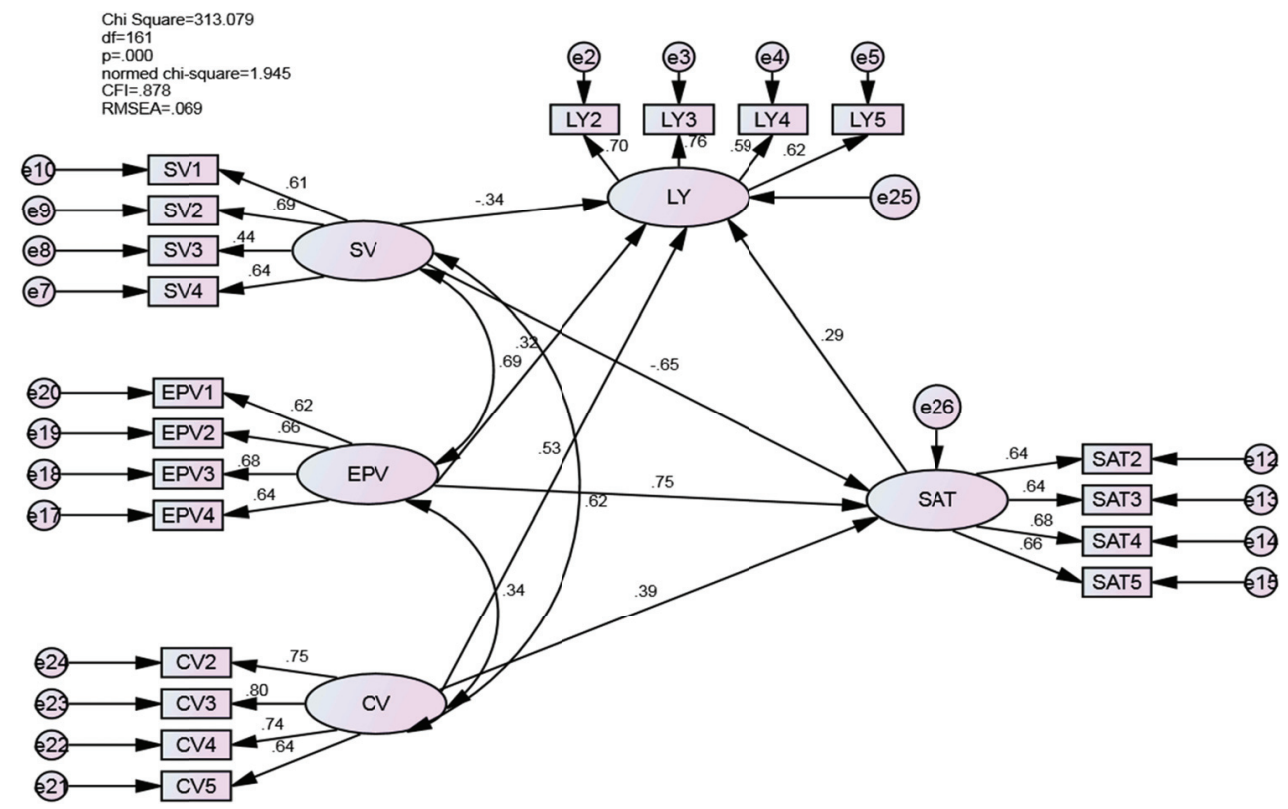

Table 8

Mediator analysis $=$ Satisfaction

\begin{tabular}{|c|c|c|c|c|c|c|c|}
\hline & & & Estimate & S.E. & C.R. & $\mathbf{P}$ & Label \\
\hline SAT & $<---$ & SV & -.245 & .125 & -1.961 & .050 & \\
\hline SAT & $<---$ & EPV & .444 & .128 & 3.477 & $* * *$ & \\
\hline SAT & $<---$ & $\mathrm{CV}$ & .190 & .093 & 2.051 & .040 & \\
\hline LY & $<---$ & SAT & .575 & .112 & 5.122 & $* * *$ & $\mathrm{~b}$ \\
\hline LY & $<---$ & SV & .004 & .073 & .048 & .962 & \\
\hline LY & $<---$ & EPV & .000 & & & & \\
\hline LY & $<---$ & $\mathrm{CV}$ & .247 & .082 & 3.011 & .003 & \\
\hline
\end{tabular}


Table 9

SAT as complete mediator between loyalty and CPV dimensions

\begin{tabular}{|c|c|c|c|c|c|c|c|}
\hline & & & Estimate & S.E. & C.R. & $\mathbf{P}$ & Label \\
\hline SAT & $<---$ & SV & -.348 & .129 & -2.701 & .007 & \\
\hline SAT & $<---$ & EPV & .474 & .128 & 3.697 & $* * *$ & \\
\hline SAT & $<---$ & $\mathrm{CV}$ & .317 & .095 & 3.351 & $* * *$ & \\
\hline LY & $<---$ & SAT & .718 & .133 & 5.406 & $* * *$ & \\
\hline LY2 & $<---$ & LY & 1.218 & .159 & 7.654 & $* * *$ & \\
\hline LY3 & $<---$ & LY & 1.244 & .157 & 7.939 & $* * *$ & \\
\hline LY4 & $<---$ & LY & 1.062 & .162 & 6.563 & $* * *$ & \\
\hline
\end{tabular}

The above mediator analysis in Figure 6 shows that the model is a good fit since all the benchmark values are achieved except CFI, which is 0.878 . Since the value is very close to 0.9 , the model will be accepted as RMSEA is below 0.08 (0.069). This means that the model is parsimonious as the values are close to 0.9.

Also similarly when all the SAT is tested as a complete mediator with loyalty, the path analysis is shown as above. This shows that SAT is a partial mediator rather than a complete mediator. Therefore, Hypothesis 8 is accepted since it is not a complete mediator.

\section{CONCLUSION}

Out of 8 hypotheses, 5 were accepted, and 3 were rejected. One was rejected as the study found that social values have a negative influence on satisfaction, which is contradictory to Hypothesis 1. Overall, this study concluded that EPV and CV have a positive and significant impact on SAT. Also EPV and SAT have a positive and significant impact on brand loyalty. However, SV has a negative impact on SAT and loyalty in the full model and the mediator model as well. Therefore, EPV and CV are important dimensions or values associated with automobile brands in Saudi Arabia and they affect customer satisfactions and brand loyalty.

This study is also important for automobile manufacturers and dealers as regards allocation of resources and designing marketing campaigns. Managers must ensure that they are aware of the epistemic and social values associated with the cars in the Saudi Arabian market. Similarly, what is important for Saudi Arabian customers is the acceptance of their friends, family and colleagues when they buy an automobile. This means that the existing customers' perception and their satisfaction might result in positive word of mouth causing their relatives, colleagues and others to purchase the product from the same company or brand. Marketers and companies should consider social acceptance and must engage in constantly identifying the customer needs and wants.

For future researchers, it is important to increase the sample size and use a more appropriate sample design and data collection approach using appropriate strata based on the market share or based on the number of vehicles of each brand available on the market.

\section{COMPETING INTERESTS}

The author has declared that no competing interests exist. 


\section{References}

Abu Bakar, A.R, Al Ruwais, N.M. and Othman, A. R. (2013) 'Customer Net Value: a Service Gap Perspective from Saudi Arabia', Global Journal of Business Research, Vol. 7 No. 4, pp. 19-33, (e-journal). Retrieved 24.10.2016 from https://papers.ssrn.com/sol3/papers.cfm?abstract_id=2239239.

Abu Bakar, A.R. (2014) 'Customer store loyalty in the context of customer perceived value in Saudi Arabia', Journal of Contemporary Research in Business, Vol. 5 No. 12, pp. 442-460, (e-journal). Retrieved 16.03.2016 from http://journal-archieves36.webs.com/442-460apr14.pdf.

Alsheikh, L. and Bojei, J. (2014) 'Determinants affecting customer's intention to adopt mobile banking in Saudi Arabia', International Arab Journal of e-Technology, Vol. 3 No. 4, pp. 210-219, (e-journal). Retrieved 29.10.2014 from http://www.iajet.org/iajet_files/vol.3/no.\%204/2-58519.pdf.

Anderson, J.C. and Gerbing, D.W. (1988) 'Structural equation modeling in practice: a review and recommended twostep approach', Psychological Bulletin, Vol. 103, pp. 411-23.

Bakon, K.A. and Hassan, Z. (2013) 'Perceived value of smartphone and its impact on deviant behaviour: An investigation on higher education students in Malaysia', International Journal of Information System and Engineering (IJISE), Vol. 2 No. 1, pp. 38-55.

Bentler, P.M. (2004) EQS 6 Structural Equations Program Manual, Multivariate Software, Encino, CA.

Calabuig, F., Núñez-Pomar, J., Prado-Gascó, V. and Ano, V. (2014) 'Effect of price increases on future intentions of sport consumers', Journal of Business Research, Vol. 67 No. 5, pp. 729-733.

Chang, E.C. and Tseng, Y.F. (2013) 'Research note: E-store image, perceived value and perceived risk', Journal of Business Research, Vol. 66 No. 7, pp. 864-870.

Cheng, M.S., Wang, S.T., Lin, Y.C. and Vivek, S.D. (2009) 'Why Do Customers Utilize the Internet as a Retailing Platform?', Asia Pacific Journal of Marketing, Vol. 21 No. 1, pp. 144-160.

Chon, K.-S. (1992) 'Self-Image/Destination Image Congruity', Annals of Tourism Research, Vol. 19 No. 2 , pp. $360-363$.

Desmet, P. (2014) 'How retailer money-back guarantees influence consumer preferences for retailer versus national brands', Journal of Business Research, Vol. 67 No. 9, pp. 1971-1978.

Dolnicar, S., Grun, B., Leisch, F. and Rossiter, J. (2011) Three good reasons NOT to use five and seven point Likert items. CAUTHE 2011: 21st CAUTHE National Conference, Adelaide, Australia, 8-11 February. Retrieved 25.03.2016 from http://ro.uow.edu.au/cgi/viewcontent.cgi?article=1821\&context=commpapers.

Ehsani, Z. and Hashim, N. (2015) 'Effect of customer perceived value on customer relationship management performance', International Journal of Science, Commerce and Humanities, Vol. 3 No. 1, pp. 139-146.

Eid, M.I. (2011) 'Determinants of e-commerce customer satisfaction, trust, and loyalty in Saudi Arabia', Journal of electronic commerce research, Vol. 12 No. 1, pp. 78-93, (e- journal). Retrieved 29.10.2014 from http://www. csulb.edu/journals/jecr/issues/20111/Paper5.pdf.

Field, A.P. (2005) Discovering Statistics Using SPSS for Windows. London: Sage Publications.

Fornell, C. and Larcker, D. (1981) 'Evaluating structural equation models with unobservable variables and measurement error', Journal of Marketing Research, Vol. 18 No. 1, pp. 39-50.

Hair, J.F., Black, W.C., Babin, B.J and Anderson, R.E. (2009) Multivariate data analysis: A global perspective, 7th Ed. New Jersey: Pearson Education Inc.

Haq, A.U. (2012) 'Satisfaction towards customer loyalty in auto-mobile industry of Pakistan', International Journal of Management and Business Research, Vol. 2 No. 4, pp. 363-371.

Holmes-Smith, P. (2001) Introduction to Structural Equation Modeling Using LISREAL, ACSPRI-Winter Training Program, Perth.

Hu, L.T. and Bentler, P.M. (1999) 'Cutoff Criteria for Fit Indexes in Covariance Structure Analysis: Conventional Criteria Versus New Alternatives', Structural Equation Modeling, Vol. 6 No. 1, pp. 1-55.

Hur, W.M., Kim, Y. and Park, K. (2013) 'Assessing the effects of perceived value and satisfaction on customer loyalty: A 'Green' perspective', Corporate social responsibility and environmental management, Vol. 20 No. 3, pp. 146-156.

Jalilvand, M, R. and Samiei, N. (2012) 'The effect of electronic word of mouth on brand image and purchase intention: An empirical study in the automobile industry in Iran', Marketing Intelligence \& Planning, Vol. 30 No. 4, pp. 460-476.

Kline, R.B. (1998) Principles and Practice of Structural Equation Modeling. New York, NY: Guilford.

Lee, S., Scott, D. and Kim, H. (2008) 'Celebrity fan involvement and destination perceptions', Annals of Tourism Research, Vol. 35 No. 3, pp. 809-832.

Leelakulthanit, O. and Hongcharu, B. (2012) 'Perceived customer value regarding eco-cars', Journal of Global Business Management, Vol. 8 No. 1, p. 74.

Loureiro, S.M., Sardinha, I.M.D. and Reijnders, L. (2012). The effect of corporate social responsibility on consumer satisfaction and perceived value: The case of the automobile industry sector in Portugal. Journal of Cleaner Production, Vol. 37, pp. 172-178. 
Mahika, E.-C. (2011) 'Current trends in tourist motivation', Cactus Tourism Journal, Vol. 2 No. 2, pp. 15-24.

Miguens, J., Baggio, R. and Costa, C. (2008) Social media and Tourism Destinations: Trip Advisor Case Study, Aveiro, s.n., pp. 26-28.

Moosa, M.Y. and Hassan, Z. (2015) 'Customer Perceived associated with Automobiles and Brand Loyalty', International Journal of Accounting and Business Management, Vol. 3 No. 1, pp. 1-16.

Nunnally, J.C. and Bernstein, I.H. (1994) Psychometric Theory, 3rd ed. New York, NY: McGraw-Hill.

Oliver, R.L. and Swan, J.E. (1989) 'Consumer perceptions of interpersonal equity and satisfaction in transactions: a field survey approach', The Journal of Marketing, Vol. 53 No. 2, pp. 21-35.

Parasuraman, A. and Grewal, D. (2000) 'The impact of technology on the quality - Value loyalty chain: A research agenda', Journal of Academy of Marketing Science, Vol. 28 No. 1, pp. 168-174.

Payne, A. and Holt, S. (2001) 'Diagnosing customer value: integrating the value process and relationship marketing', British Journal of Management, Vol. 12 No. 2, pp. 159-182.

Peng, L. and Liang, S. (2013) 'Purchase intention in e-commerce platform: A time limited promotion perspective', Proceedings of the Thirteen International Conferences on Electronic Business, 1-4 December, p. 56.

Sheth, J.N., Newman, B.I. and Gross, B.L. (1991) 'Why we buy what we buy: A theory of consumption values', Journal of Business Research, Vol. 22 No. 2, pp. 159-170.

Sweeney, J.C. and Soutar, G.N. (2001) 'The Development of a Multiple Item Scale', Journal of Retailing, Vol. 77 No. 2, pp. 203-220.

Tabassum N., Zafar, Z., Ali, A., Alam, A. and Ali, M. (2013) 'The Effect of Value Perception on Customer Loyalty and Satisfaction’, IOSR Journal of Business and Management, Vol. 12 No. 6, pp. 62-69, (e-journal). Retrieved from http://iosrjournals.org/iosr-jbm/papers/Vol12-issue6/G01266269.pdf.

Tu, Y.T., Lin, S.Y. and Hsu, T.K. (2013) 'The Impact of Brand Image and Customer Commitment on Loyalty: An Empirical Study of Automobile Sector', Information Management and Business Review, Vol. 5 No. 4, p. 181.

Ulaga, W. and Chacour, S. (2001) 'Measuring customer perceived value in business markets. A Prerequisite for Marketing Strategy Development and Implementation', Industrial Marketing Management, Vol. 30 No. 6, pp. 525-540.

Vera, J. and Trujillo, A. (2013) 'Service quality dimensions and superior customer perceived value in retail banks: An empirical study on Mexican consumers', Journal of Retailing and Consumer Services, Vol. 20 No. 6 , pp. 579-586.

Vuuren, C.V. and Slabbert, E.(2011) Travel Motivations and Behaviour of tourists to a South African. Algarve, s.n

Wu, L.Y., Chen, K.Y., Chen, P.Y. and Cheng, S.L. (2014) 'Perceived value, transaction cost, and repurchase-intention in online shopping: A relational exchange perspective', Journal of Business Research, Vol. 67 No. 1, pp. 2768-2776.

Xiucheng, F. and Yunlai, Z. (2006) 'A study on emotional impact mechanism of impulsive purchase', Social Scientist, Vol. 118 No. 2, pp. 148-151.

Yang, K. and Jolly, L.D. (2009) 'The effects of consumer perceived value and subjective norm on mobile data service adoption between American and Korean consumers', Journal of Retailing and Consumer Services, Vol. 16 No. 6, pp. 502-508.

Yee, C.J. and San, N.C. (2011) 'Consumers' perceived quality, perceived value and perceived risk towards purchase decision on automobile', American Journal of Economics and Business Administration, Vol. 3 No. 1, pp. 47-57.

Yusof, J.M., Singh, G.K.B. and Razak, R.A. (2013) 'Purchase intention of environment-friendly automobile', Procedia-Social and Behavioral Sciences, Vol. 85, pp. 400-410. Elsevier.

Zauner, A., Koller, M. and Hatak, I. (2015). 'Customer perceived value-Conceptualization and avenues for future research', Applied Psychology, Vol. 2, pp. 1-17, (e-journal). Retrieved from http://doc.utwente.nl/99534/1/ ZaunerKollerHatak2015_CogentPsychology.pdf.

Ziethaml, V.A. (1988) 'Consumer perception of price, quality, and value: a means-end model and synthesis of evidence', Journal of Marketing, Vol. 52 No. 3, pp. 2-22. 